\title{
Intervensi Program Bimbingan dan Konseling dalam Mengatasi Bullying Siswa Madrasah Aliyah Negeri Salatiga
}

\author{
Andar Ifazatul Nurlatifah \\ IAIN Salatiga, Jawa Tengah, Indonesia \\ andarifa@iainsalatiga.ac.id
}

\begin{abstract}
Abstrak
Tulisan ini merupakan penelitian mixed method dengan desain concurrent triangulation untuk memaparkan fenomena bullying di kalangan siswa MAN Kota Salatiga, intervensi bimbingan dan konseling untuk mengatasinya, dan bentuk ideal program bimbingan dan konseling untuk mengatasi bullying di MAN Kota Salatiga. Data kuantitatif dikumpulkan menggunakan skala terhadap 157 responden untuk mengukur pemahaman dan keterlibatan siswa dengan bullying; sedangkan data kualitatif diperoleh melalui wawancara terhadap guru BK dan siswa, serta FGD yang diikuti oleh dosen dan guru BK. Rata-rata pemahaman siswa terhadap konsep bullying adalah sebesar 73,41\%, rata-rata keterlibatan siswa sebagai korban dan pelaku bullying adalah $34,13 \%$ dan 34,25\%, sedangkan keterlibatan siswa sebagai saksi bullying adalah 44,76\%. Dari segi demografis, terdapat perbedaan rata-rata pemahaman konsep dan keterlibatan siswa dalam bullying antara laki-laki dan perempuan. Intervensi yang dilakukan oleh guru BK MAN Kota Salatiga berfokus pada layanan responsif berupa upaya kuratif terhadap korban dan pelaku bullying, sedangkan bentuk ideal program penangan kasus bullying dilakukan secara merata dalam bingkai pelayanan dasar, pelayanan responsif, pelayanan perencanaan individual, dan dukungan sistem terhadap pelaku, korban, maupun saksi bullying.
\end{abstract}

Kata kunci: bimbingan dan konseling, bullying, intervensi, korban, pelaku, saksi

\section{Abstract}

The Intervention of Guidance And Counseling Program to Overcome The Bullying of MAN Salatiga Students. This article a mixed method research with concurrent triangulation design to 
examine (1) the phenomenon of bullying at MAN Salatiga, (2) the guidance and counseling intervention to deal with bullying at MAN Salatiga, and (3) the ideal guidance and counseling program to overcome bullying at MAN Salatiga. Scale delivered to 157 respondents to measure students' understanding and involvement in bullying. Interviews with students, guidance and counseling teachers, and FGD followed by lecturers and counselors used to collect information about bullying and bullying intervention. The results of the study revealed that students' understanding of the concept of bullying is $73.41 \%$, $44.76 \%$ students involved in bullying as witness; $34.13 \%$ as victim; and $34.25 \%$ as bully. There are differences between men and women in understanding of bullying concept and the involvement in bullying. The guidance and counseling teachers' interventions in dealing with bullying are focused on guidance and counseling responsive services in the form of curative efforts to the victim and bully. Therefore, the ideal program in dealing with bullying is carried out evenly in the frame of guidance and counseling basic services, responsive services, individual planning services, and system support to the victim, the bully, and the witness.

Keywords: guidance and counseling, bullying, intervention, victim, bully, witness

\section{A. Pendahuluan}

Karakteristik siswa usia madrasah aliyah adalah sedang dalam proses peningkatan kualitas hubungan pertemanan dan tertarik untuk membentuk kelompok besar (Brooks, 2004:335). Kedekatan dengan teman sekelompok pada kasus-kasus tertentu dapat menimbulkan side effect berupa gap berlebihan yang dapat berkembang menjadi perilaku bullying. Fenomena bullying di kalangan siswa madrasah aliyah ini dapat berbentuk kekerasan fisik, kekerasan verbal, dan penekanan psikologis (Olweus, 1996). Keterlibatan siswa dengan bullying selain dikarenakan faktor individual (Farrington \& Baldry, 2010), juga dapat disebabkan oleh alasan lain yang lebih kompleks (Nassem, 2017).

Menurut Clark, Pendidikan saat ini lebih cenderung menekankan pada penguasaan aspek kognisi namun lemah pada pengembangan kepribadian beriman, bertakwa, kreatifitas serta perasaan kemanusiaan. Sistem sekolah yang berorientasi pengembangan otak kiri (untuk menguasai iptek) sering membuat peserta didik tertekan dan jenuh, frustasi, sehingga memicu konflik dalam diri peserta didik. Keadaan tersebut memicu peserta didik memiliki kecerdasan yang 
tinggi tetapi tidak memiliki kepedulian sosial terhadap orang lain. Kondisi yang tidak seimbang antara pesatnya kemajuan otak dengan kondisi perasaan akan memunculkan rasa cemas pada peserta didik di lingkungan pendidikan terhadap semua aturan kependidikan seperti tata tertib Madrasah, kedisiplinan, etika interaksi dengan guru maupun teman sebaya (Farida 2017:45). Bullying menjadi kasus yang marak terjadi dilingkungan pendidikan akibat kondisi dimana peserta didik kurang memiliki kepedulian sosial dan kepekaan perasaan terhadap yang lainya.

Bullying merupakan salah satu fenomena yang relatif sulit dideteksi (Frey, 2005). Pada umumnya yang terekspos media biasanya adalah bullying melalui kekerasan fisik, padahal bullying verbal dan penekanan psikologis pun memiliki nilai destruktif dan efek traumatis yang tidak kalah besarnya jika dibandingkan dengan bullying fisik. Efek buruk bullying ini tidak hanya dirasakan oleh korban (Bond, dkk., 2001; Lösel \& Bender, 2011; McGee, dkk., 2011), tetapi juga dialami oleh pelaku (McIntyre \& Franks, tt.; Wolke, dkk., 2013) dan saksi peristiwa bullying (Rivers, dkk., 2009:211-223). Secara khusus, pengaruh bullying terhadap kesehatan mental korban dikarenakan adanya respon fisiologis, distorsi kognitif, dan oversensitif terhadap penanda (Arseneault, dkk., 2010).

Fenomena bullying yang dialami konseli mendapat respon konselor (Jacobsen \& Bauman, 2007). Masifnya fenomena bullying diiringi dengan penerapan program anti-bullying yang marak digencarkan di berbagai negara. Keberhasilan program anti-bullying tersebut terbukti efektif menurunkan 20-23\% bullying di sekolah (Ttofi dan Farrington, 2009). Namun, berfokus pada legislasi hukuman dan mengkriminalkan perilaku bullying ternyata tetap tidak cukup melindungi kelompok siswa yang rentan terhadap bullying (Hawrylak dan Donoghue, 2016).

Upaya penanganan bullying perlu mendapat perhatian dalam program BK yang disusun oleh guru BK sebagai salah satu bagian dari kompetensi profesionalnya sesuai dengan Permendiknas No. 27 Tahun 2008. Berangkat dari kebutuhan tersebut, penelitian ini bertujuan untuk mengetahui (1) fenomena bullying di kalangan siswa Madrasah Aliyah Negeri Kota Salatiga, (2) intervensi bimbingan dan konseling yang diterapkan untuk mengatasi bullying di Madrasah Aliyah Negeri Kota Salatiga, (3) bentuk ideal program bimbingan dan konseling untuk mengatasi bullying di Madrasah Aliyah Negeri Kota Salatiga.

Penelitian ini merupakan penelitian mixed method menggunakan desain concurrent triangulation dengan proporsi kuantitatif dan kualitatif yang setara 
(QUAN + QUAL), baik pada proses pengumpulan data maupun analisis data. Penelitian bertempat di Madrasah Aliyah Negeri Kota Salatiga pada tanggal 26 Juni s.d. 1 Oktober 2018. Data kuantitatif dikumpulkan menggunakan skala, sedangkan data kualitatif dikumpulkan melalui wawancara terhadap guru BK dan siswa serta melalui Focused Group Discussion guru BK MAN Kota Salatiga. Skala disebarkan kepada 157 responden (52 laki-laki dan 105 perempuan) untuk mengukur pemahaman siswa tentang konsep bullying dan keterlibatan siswa dalam bullying. Instrumen tersebut telah melalui tahap professional judgment oleh praktisi BK, akademisi BK, dan akademisi bidang psikologi; serta melalui uji validitas instrumen dengan pearson's product-moment dan uji reliabilitas internal consistency dengan alfa cronbach yang menghasilkan angka 0,895. Data hasil skala diolah menggunakan analisis frekuensi/proporsi dan analisis mode melalui program SPSS 16.0. Data kualitatif yang dikumpulkan melalui wawancara dan FGD diolah secara deskriptif analitis kemudian disintesiskan dengan data kuantitatif.

\section{B. Pembahasan}

\section{Bullying}

Bullying adalah penggunaan kekuatan oleh pihak yang lebih kuat/superior untuk mengintimidasi, melukai, atau menghina pihak yang lebih lemah/inferior (Regoli dan Hewitt, 2006:331), yang ditandai dengan adanya perbedaan kekuasaan/kekuatan antara pelaku dengan korban, adanya perulangan kejadian, adanya unsur kesengajaan, dan menimbulkan teror (Coloroso, 2007:56-57). Bullying dapat berupa tindakan fisik, verbal, maupun penekanan psikologis yang melibatkan berbagai pihak, antara lain pelaku/bully, korban/victim/target, assistant, dan saksi. Siswa yang cenderung murni menjadi pelaku bullying disebut pure bully. Di sisi lain, siswa yang menjadi pelaku bullying namun juga menjadi korban bullying disebut target-agresor atau target-provokatif. Mereka terkadang dibantu oleh asistennya (assistant) misalnya untuk memegangi korban atau menyiapkan perlengkapan. Selain pihak tersebut, juga terdapat tiga macam saksi dalam bullying, yaitu yang turut menertawakan korban atau mengajak orang lain untuk menonton peristiwa tersebut (reinforcer); yang hendak membantu korban (defender); dan yang menyaksikan tetapi bersikap acuh tak acuh (outsider). 


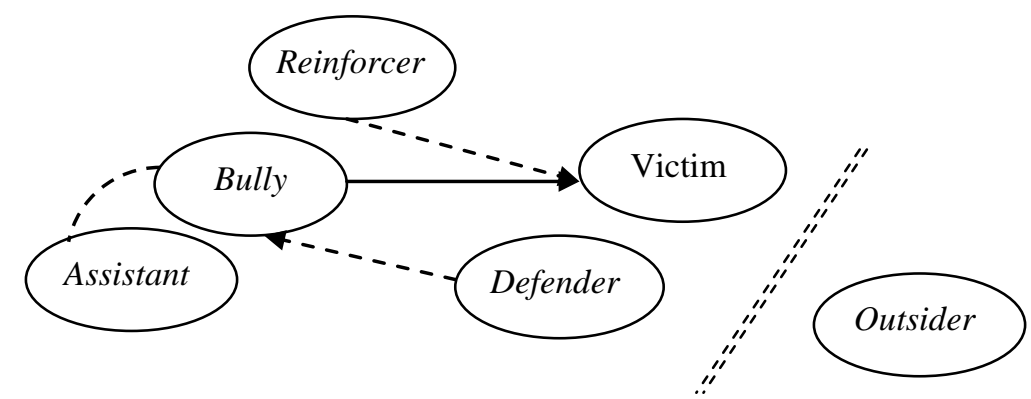

Pihak yang Terlibat dalam Bullying (Nurlatifah, 2017:424)

\section{Program Bimbingan dan Konseling}

Program bimbingan dan konseling terbagi menjadi empat komponen, yaitu pelayanan dasar, pelayanan responsif, pelayanan perencanaan individual, dan dukungan sistem. Program bimbingan dan konseling memiliki ruang lingkup yang menyeluruh (bidang pribadi-sosial, bidang belajar, dan bidang karir), lebih berorientasi pada pencegahan, dan bertujuan untuk mengembangkan potensi siswa (Suherman, 2007:59-60). Sasarannya lebih kepada seluruh siswa, baik yang bermasalah maupun yang tidak sedang mengalami masalah.

Pelayanan dasar diperuntukkan bagi seluruh siswa/konseli dan lebih berorientasi jangka panjang. Kurikulum BK dapat pula difungsikan sebagai panduan dalam pelayanan dasar. Layanan bertujuan membantu siswa dalam mengembangkan perilaku efektif dan keterampilan hidup yang mengacu pada tugas-tugas perkembangan (Nurihsan, 2011:17). Peayanan dasar dapat diterapkan dalam bidang pribadi, sosial, belajar, maupun karir. Strategi pelayanannya dapat dilakukan melalui bimbingan klasikal, pelayanan orientasi, pelayanan informasi, bimbingan kelompok, dan aplikasi instrumentasi (Direktorat Jenderal Peningkatan Mutu Pendidik dan Tenaga Kependidikan, 2007:224-225).

Pelayanan responsif merupakan kegiatan untuk menemukan kebutuhan dan persoalan konseli yang mendesak, yang dapat dilakukan dengan strategi konsultasi, konseling individual dan kelompok kecil, referal, fasilitasi oleh teman sebaya, kolaborasi (dengan guru mata pelajaran, orang tua konseli, dan pihakpihak lain), konferensi kasus, kunjungan rumah, dan konseling krisis/konseling jangka pendek dan bersifat sementara untuk menangani situasi darurat (Direktorat Jenderal Peningkatan Mutu Pendidik dan Tenaga Kependidikan, 2007: 226-228; Suherman, 2007:80-82). Pelayanan responsif bertujuan membantu memenuhi kebutuhan yang dirasakan sangat penting dan mendesak oleh siswa. 
Dalam Pelayanan perencanaan individual, konselor membantu konseli agar konseli dengan kemampuannya sendiri dapat menganalisis kelemahan dan kekuatannya serta menelaah peluang yang ada sehingga dapat melakukan perencanaan untuk kehidupannya terkait kehidupan mendatang. Perencanaan individual bertujuan membantu individu dalam memahami diri dan lingkungan sehingga dapat membuat dan mengimplementasikan rencana pendidikan, karir, sosial, dan pribadinya, serta mampu melakukan kegitan berkaitan dengan hal tersebut. Strategi pelayanannya dapat diterapkan secara perorangan maupun kelompok, misalnya dengan cara diskusi dan kunjungan industri.

Dukungan sistem adalah aktivitas manajemen yang membentuk, memelihara, dan meningkatkan efektivitas dan efisiensi BK di sekolah secara keseluruhan. Tujuan dukungan sistem adalah memantapkan, memelihara, dan meningkatkan program BK secara menyeluruh melalui pengembangan profesionalitas, hubungan masyarakat dan staf, konsultasi, manajemen program, serta penelitian dan pengembangan (Suherman, 2007:82-84; Nurihsan, 2011:19). Guru BK dapat melakukan riset dan pengembangan dengan melakukan penelitian dan mengoptimalkan perannya sebagai anggota organisasi profesi (Direktorat Jenderal Peningkatan Mutu Pendidik dan Tenaga Kependidikan, 2007:229-230). Tampilan kepustakaan yang menyediakan berbagai bahan pustaka yang dapat membantu siswa dalam kaitannya dengan layanan BK juga merupakan pendukung dalam BK (Febrini, 2011:89).

\section{Pemahaman Siswa MAN tentang Konsep Bullying}

Sebanyak 20 item pada bagian pertama skala menelisik pemahaman responden tentang konsep bullying. Semakin tinggi hasil jawaban responden mengindikasikan semakin tinggi pula pemahaman responden tersebut tentang konsep bullying. Skor kumulatif bergerak dari 0 s.d. 100, dengan hasil pemerolehan skor terendah adalah 5 (satu orang siswa) dan skor tertinggi adalah 100 (diraih oleh sembilan siswa). Rata-rata skor, nilai tengah, dan modus berturut-turut adalah sebesar 73,41; 75,00; dan 80,00. Rata-rata pemahaman siswa tentang konsep bullying adalah 73,41 dari nilai maksimal 100. Hasil analisis terhadap jawaban responden ditampilkan melalui tabel Analisis Statistik Deskriptif Pemahaman Konsep Bullying dan digambarkan melalui Histogram sebaran Pemahaman Konsep Bullying.

Tabel 1. Analisis Statistik Deskriptif Pemahaman Konsep Bullying

\begin{tabular}{llll}
\hline $\mathrm{N}$ & Valid & 157 Missing & 0 \\
\hline
\end{tabular}




\begin{tabular}{lrlr}
\hline Mean & 73.41 & Std. Error of Skewness & .194 \\
\hline $\begin{array}{l}\text { Std. Error of } \\
\text { Mean }\end{array}$ & 1.52 & Kurtosis & .689 \\
\hline Median & 75.00 & Std. Error of Kurtosis & .385 \\
\hline Mode & 80.00 & Range & 95.00 \\
\hline Std. Deviation & 19.05 & Minimum & 5.00 \\
\hline Variance & 362.83 & Maximum & 100.00 \\
\hline Skewness & -.912 & Sum & 11525.00 \\
\hline
\end{tabular}

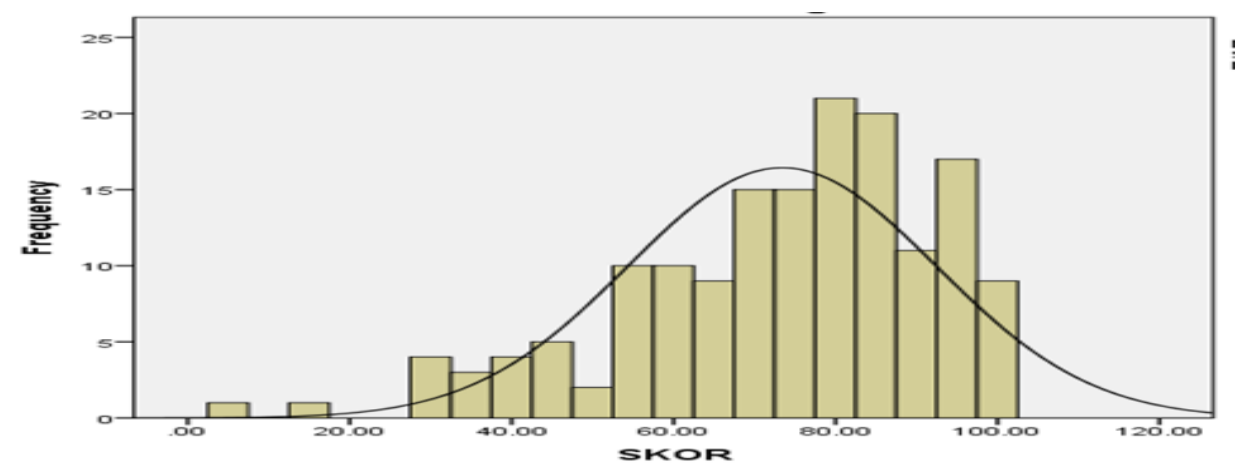

Histogram sebaran Pemahaman Konsep Bullying

Hasil tersebut diperjelas dengan data kualitatif melalui wawancara terhadap dua belas siswa bahwa mereka memahami konsep bullying secara umum namun mengalami kesulitan melihat konsep tersebut dalam konteks kehidupan sehari-hari yang mereka alami. Salah satu responden yang memperoleh skor paling rendah, yaitu 5 dari rentang 0 s.d. 100, ketika diklarifikasi melalui lembar pengerjaan skalanya menunjukkan bahwa responden memperoleh skor 5 bukan karena responden tidak paham mengenai konsep bullying, namun lebih tepatnya karena responden tidak bersungguh-sungguh dalam mengisi skala. Item yang dikerjakan adalah item C101 sementara item lain diisi dengan pilihan "tidak tahu".

\section{Keterlibatan Siswa dalam Bullying}

Hasil skala pada bagian kedua yang dituangkan dalam 42 item pernyataan menunjukkan keterlibatan responden dalam bullying, yaitu sebagai saksi, korban, dan pelaku bullying. Semakin tinggi skor jawaban mengindikasikan semakin tinggi keterlibatan responden dalam bullying. Hasil analisis terhadap data tersebut ditampilkan melalui tabel Analisis Statistik Deskriptif Keterlibatan Siswa dalam Bullying.

Tabel 2. Analisis Statistik Deskriptif Keterlibatan Siswa dalam Bullying 


\begin{tabular}{lrrrrr}
\hline & \multicolumn{1}{c}{ Saksi } & Korban & Pelaku & Keseluruhan \\
\hline $\mathrm{N}$ & 157 & 157 & 157 & 157 \\
& Valid & 0 & 0 & 0 & 0 \\
\cline { 2 - 6 } Mean & 24.62 & 32.41 & 20.55 & 77.58 \\
\hline Std. Error of Mean & .56 & .67 & .54 & 1.35 \\
\hline Median & 23.00 & 32.00 & 19.00 & 75.00 \\
\hline Mode & 22.00 & $30.00^{\mathrm{a}}$ & 18.00 & 69.00 \\
\hline Std. Deviation & 6.96 & 8.39 & 6.75 & 16.90 \\
\hline Variance & 48.40 & 70.45 & 45.61 & 285.55 \\
\hline Skewness & .977 & .728 & 1.127 & .882 \\
\hline Std. Error of & .194 & .194 & .194 & .194 \\
Skewness & .955 & 3.247 & 2.453 & 2.442 \\
\hline Kurtosis & .385 & .385 & .385 & .385 \\
\hline Std. Error of Kurtosis & 35.00 & 65.00 & 49.00 & 119.00 \\
\hline Range & 13.00 & .00 & .00 & 18.00 \\
\hline Minimum & 48.00 & 65.00 & 49.00 & 137.00 \\
\hline Maximum & 3866.00 & 5088.00 & 3226.00 & 12180.00 \\
\hline Sum & \multicolumn{1}{c}{ Sum } & &
\end{tabular}

Rata-rata keterlibatan responden sebagai saksi, korban, pelaku bullying, dan secara keseluruhan berturut-turut adalah sebesar 24,62; 32,42; 2,55; dan 77,58 . Rata-rata keterlibatan siswa sebagai saksi bullying berada pada kategori sedang, yaitu 24,62 dari skor maksimal 55 (44,76\%); sebagai korban bullying berada pada kategori rendah, yaitu 32,42 dari skor maksimal 95 (34,13\%); sebagai pelaku bullying berada pada kategori rendah, yaitu 20,55 dari skor maksimal 60 (34,25\%); dan secara keseluruhan adalah berada pada kategori rendah, yaitu sebesar 77,58 dari skor maksimal 210 (36,94\%). Keterlibatan siswa dalam peristiwa bullying, sebagai saksi, korban, dan pelaku bullying secara lebih jelas ditunjukkan melalui diagram garis yang menunjukkan pola garis yang sejajar.

Keterlibatan Siswa dalam Bullying

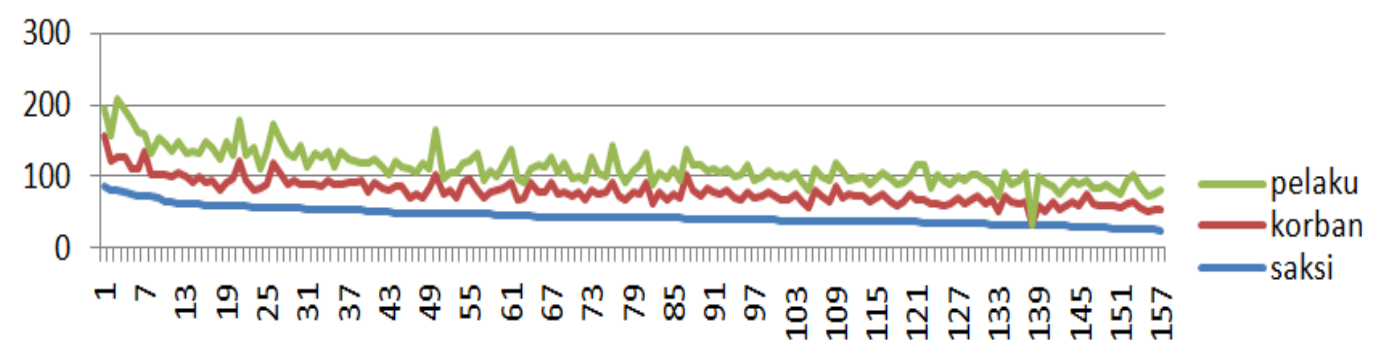

Data angket apabila dianalisis menurut segi demografis berupa jenis kelamin akan menghasilkan perbedaan rata-rata pemahaman konsep bullying 
serta pengamatan dan pengalaman sebagai saksi, korban, dan pelaku bullying antara laki-laki dan perempuan. Rata-rata pemahaman perempuan dan laki-laki mengenai konsep bullying berbeda. Laki-laki relatif lebih rentan terlibat sebagai saksi, korban, maupun pelaku bullying dibandingkan dengan perempuan.

Tabel 3. Pemahaman terhadap Konsep Bullying dan Keterlibatan dalam Bullying

\begin{tabular}{llrrrr}
\hline Jenis Kelamin & Konsep & Saksi & Korban & Pelaku \\
\hline \multirow{2}{*}{$\begin{array}{l}\text { Laki- } \\
\text { Laki }\end{array}$} & Mean & 62.02 & 27.67 & 32.75 & 24.00 \\
\cline { 2 - 6 } & $\mathrm{N}$ & 52 & 52 & 52 & 52 \\
\cline { 2 - 6 } & $\begin{array}{l}\text { Std. } \\
\text { Dev. }\end{array}$ & 21.92 & 8.15 & 11.68 & 8.77 \\
\hline $\begin{array}{l}\text { Perem } \\
\text {-puan }\end{array}$ & Mean & 79.05 & 23.11 & 32.24 & 18.84 \\
\cline { 2 - 6 } & $\mathrm{N}$ & 105 & 105 & 105 & 105 \\
\cline { 2 - 6 } & $\begin{array}{l}\text { Std. } \\
\text { Dev. }\end{array}$ & 14.55 & 5.75 & 6.22 & 4.67 \\
\hline Total & Mean & 73.41 & 24.62 & 32.41 & 20.55 \\
\cline { 2 - 6 } & $\mathrm{N}$ & 157 & 157 & 157 & 157 \\
\cline { 2 - 6 } & $\begin{array}{l}\text { Std. } \\
\text { Dev. }\end{array}$ & 19.05 & 6.96 & 8.39 & 6.75 \\
& & & & \\
\hline
\end{tabular}

Wawancara terhadap guru BK dan siswa mengenai fenomena bullying di kalangan siswa MAN Kota Salatiga menunjukkan bahwa sedikit sekali muncul peristiwa bullying yang serius di kalangan siswa. Kasus bullying yang serius bukan tidak ada melainkan jarang terjadi. Hal tersebut bukan merupakan iklim yang membudaya, melainkan hanya bersifat pengecualian saja yang dilakukan oleh siswa malasuai. Siswa secara umum mampu membaur dengan baik, interaksi sosial berlangsung dengan baik. Gap antarkelompok juga tidak terpisah secara ekstrim. Artinya, meskipun memiliki kedekatan kelompok/kohesivitas tertentu, namun sifatnya masih terbuka untuk menerima siswa lain yang berasal dari luar kelompoknya.

\section{Intervensi Program BK dalam mengatasi Kasus Bullying di MAN Salatiga}

Hasil FGD guru BK serta wawancara terhadap guru BK dan siswa terkait intervensi dalam kasus bullying di MAN Kota Salatiga menunjukkan adanya intervensi yang beragam sesuai dengan jenis dan tingkat berat-ringan bullying. Kasus bullying fisik menjadi kasus yang sesegera mungkin mendapat penanganan secara intensif dari guru bimbingan dan konseling. Guru bimbingan dan konseling berupaya menyelamatkan berbagai pihak, baik pelaku maupun korban. Dengan demikian, intervensi kasus bullying dibedakan menjadi intervensi untuk pelaku bullying dan intervensi untuk korban bullying. Masing-masing intervensi memiliki 
karakteristik penanganan khusus yang dapat dikelompokkan secara garis besar meskipun dihadapkan pada kenyataan bahwa setiap konseli memiliki karakteristik yang berbeda-beda.

Intervensi untuk korban bullying difokuskan untuk meningkatkan asertifitas korban. Hal ini didasarkan pada salah satu aspek bullying berupa adanya intimidasi/teror. Ketika korban tidak merasa terintimidasi dan adekuat untuk melakukan coping secara positif, maka korban tersebut akan dapat melalui bullying. Asertifitas membuat korban dapat menyampaikan pikiran dan perasaannya dengan lugas dan tegas, serta dapat menolak pelaku bullying dengan lugas dan tegas pula.

Intervensi untuk pelaku bullying difokuskan untuk menyentuh aspek afektif pelaku bullying sehingga pelaku terbuka perasannya untuk turut merasakan perasaan korban. Ketika siswa menunjukkan perilaku malasuai berupa bullying, guru bimbingan dan konseling berupaya menggali multifaset siswa tersebut, baik dari sisi positifnya yang mungkin dapat dikembangkan, maupun dari sisi negatifnya sebagai pembacaan kemungkinan terburuk yang dapat terjadi sebagai bahan dasar untuk membantu siswa tersebut. Guru bimbingan dan konseling utamanya berusaha menyentuh afeksi siswa agar siswa tersebut percaya dan mau menerima masukan/saran/bantuan dari guru bimbingan dan konseling secara sukarela atas dasar kemauan pribadi. Guru bimbingan dan konseling memiliki tugas utama untuk membantu siswa demi kebaikan dan masa depan siswa. Oleh karena itu, guru bimbingan dan konseling senantiasa berusaha membangun raport/ hubungan yang baik dengan siswa. Guru bimbingan dan konseling berupaya menjadi tempat yang aman bagi siswa untuk melakukan keluh kesah atas pikiran dan perasannya tanpa siswa merasa selalu dinilai dan dihakimi. Harapannya, siswa akan terketuk hatinya untuk berubah karena perubahan yang efektif adalah perubahan yang didasari oleh kemauan dan kesadaran siswa itu sendiri, bukan merupakan paksaan dari pihak lain.

Intervensi dalam hal kognitif juga memberi banyak pengaruh terhadap pelaku bullying. Pola pikir yang tepat akan membantu pelaku bullying untuk mengkompensasi perilaku negatifnya agar berubah menjadi bentuk perilaku positif yang tidak merugikan diri sendiri dan orang lain, serta sesuai dengan norma sosial lingkungannya sehingga dapat diterima oleh orang lain dengan baik. Perilaku yang sudah terbentuk dapat diintervensi dengan menggunakan penguatan positf/penguatan negatif melalui pemberian reward dan punishment. 
Ditinjau dari berat-ringan dan jenis bullying, memang benar ada tindakan bullying fisik yang dilakukan oleh siswa, namun jenis bullying yang relatif sering muncul di kelas adalah bulling verbal berupa olok-olok kepada siswa lain. Sebagai contoh kasus: seorang siswa menangis keluar dari kelas karena tidak tahan diolokolok oleh siswa lain lantaran logat bicaranya yang "unik" dan dianggap lucu. Bagi teman sekelasnya hal tersebut menjadi olok-olokan lucu dan menyenangkan sebagai bahan bercanda. Akan tetapi, korban merasa tidak nyaman dengan hal tersebut sampai suatu ketika korban memutuskan untuk lari keluar dari kelas karena sudah tidak betah. Langkah pertama yang dilakukan oleh guru adalah memberi pengertian bahwa apa yang dilakukan teman-temannya tidak dimaksudkan untuk menyakiti hatinya atau melukai perasaannya. Hal itu dilakukan karena teman-temannya menganggap logat bicaranya lucu dan unik. Itulah yang membuat teman-temannya tertawa.

Apabila kesalahan siswa merupakan pelanggaran berat dan merugikan siswa lain, sementara siswa tersebut belum menunjukkan iktikad untuk berubah, dan bentuk-bentuk intervensi yang dilakukan guru bimbingan dan konseling sudah tidak efektif lagi, maka siswa tersebut terpaksa dikenakan sanksi yang berat. Bentuk sanksi terberat adalah pengembalian siswa tersebut kepada orang tuanya (berdasarkan kebijakan dari Kepala Sekolah) yang diputuskan dengan menimbang berbagai sisi baik dan buruknya. Hal ini merupakan jalan terakhir yang sebisa mungkin dihindari oleh guru bimbingan dan konseling selama jalan lain masih dapat ditempuh. Harapannya, siswa mampu mengambil pelajaran dari konsekuensi yang menimpanya sehingga siswa dapat menunjukkan perubahan perilaku di tempat baru. Proses pengembalian siswa kepada orang tua merupakan proses berat yang semaksimal mungkin dihindari oleh pihak sekolah, baik kepala sekolah maupun guru bimbingan dan konseling.

Alasan yang mendasari munculnya bullying sering kali tidak seluruhnya bermuatan dendam atau karena adanya masalah pribadi, namun adakalanya didasari motif bercanda, ikut-ikutan teman atau solidaritas antarteman, serta iklim interaksi di kalangan siswa. Dalam kacamata teoritis, munculnya bullying dapat disebabkan oleh hal-hal berikut: pertama: secara umum faktor intrinsik dan ekstrinsik pemicu bullying terjalin secara berkelindan dan dalam praktiknya sukar untuk dipisahkan satu sama lain; kedua: perkembangan sosial siswa usia madrasah aliyah pada umumnya sudah memiliki kemampuan kolaboratif yang ditandai dengan munculnya perilaku menyesuaikan keinginan masing-masing pihak/win win solution bagi dirinya dan orang lain. Siswa yang melakukan bullying 
menunjukkan bahwa siswa tersebut belum berada pada taraf kemampuan ini atau terhambat dalam pemerolehan kecakapan tersebut; ketiga: menurut teori kelekatan, perilaku bullying dapat muncul pada seseorang yang mengalami insecure attachment pada masa kecilnya; keempat: menurut paradigma psikoanalisis, perilaku bullying dapat muncul pada diri seseorang karena didasari peristiwa tertentu di masa lalu yang berdampak sepanjang rentang kehidupannya; Kelima: menurut paradigma epigenesis, perilaku bullying dapat muncul pada diri seseorang karena orang tersebut pada masa lalu mengalami mistrust, shame and doubth, guilt, inferiority, atau role confusion; Keenam: menurut teori paradigma behavioral, perilaku bullying dapat muncul karena seseorang menirunya dari lingkungan dan orang tersebut bereaksi menurut stimulus yang sampai kepadanya; ketujuh: menurut teori pembelajaran sosial, perilaku bullying muncul karena didasari personal/ kepribadian seseorang, behavioral/ perilaku, dan environment/ lingkungan luar yang melingkupi orang tersebut; dan, Kedelapan: menurut teori pembelajaran sosiokultural, perilaku bullying muncul karena dipengaruhi interaksi dan faktor kultural yang melingkupi seseorang.

Secara umum telah diuraikan bahwa keterlibatan siswa sebagai saksi berada dalam kategori sedang (45\%), sedangkan sebagai korban dan pelaku berada dalam kategori rendah (34\%). Hal ini mengindikasikan kemungkinan adanya beberapa hal, misalnya adanya kesulitan dalam mengenali bullying oleh korban seperti dalam penelitian Samnani bahwa bentuk-bentuk perilaku bullying yang ditunjukkan melalui verbal dan penekanan psikologis akan lebih sukar diidentifikasi oleh target dan saksi bullying (Samnani, 2013). Target cenderung mengalami kebingunan dalam menanggapi bullying yang ditunjukkan secara halus. Hal tersebut dikuatkan melalui triangulasi data berdasarkan wawancara bahwa siswa memahami konsep bullying secara umum namun mengalami kesulitan melihat konsep tersebut dalam konteks kehidupan sehari-hari yang mereka alami. Indikasi lain misalnya, tingkat kesulitan untuk mendeteksi perilaku bullying sekolah dikarenakan siswa yang terampil secara sosial lebih mahir dalam menjaga rahasia bullying mereka sehingga sulit untuk dideteksi secara informal (Frey, 2005).

Intervensi yang dilakukan guru bimbingan dan konseling terkait bullying pada siswa MAN Kota Salatiga berfokus pada intervensi yang bersifat kuratif. Apabila digambarkan melalui bagan program bimbingan dan konseling komprehensif, maka intervensi ini berada pada wilayah pelayanan responsif. 


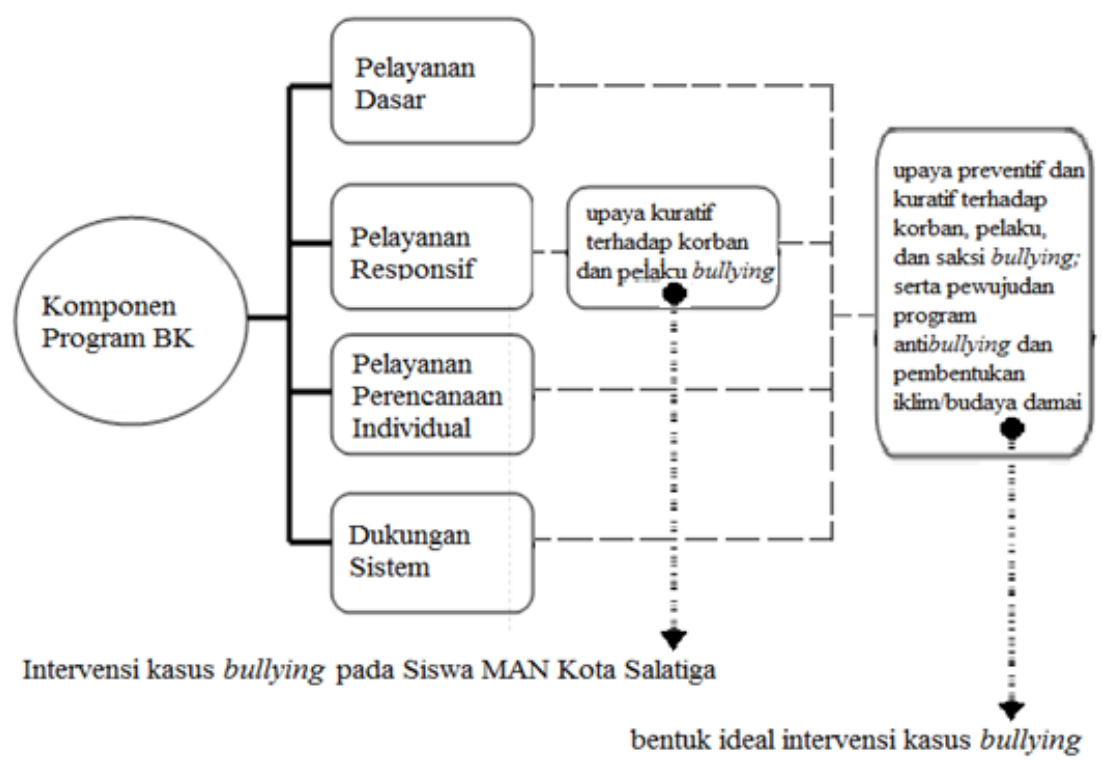

Eksplorasi intervensi kasus bullying yang dilakukan guru bimbingan dan konseling berada pada ranah pelayanan responsif sebagai langkah kuratif untuk menangani kasus bullying yang telah terjadi. Dalam pelayanan responsif ini, guru bimbingan dan konseling mengutamakan aspek kedekatan emosional dengan konseli dengan harapan bahwa konseli akan secara sadar dan sukarela melakukan perbaikan diri. Memang keberhasilan konseling, terutama pada siswa usia madrasah aliyah yang relatif telah memiliki kemandirian cara berpikir, salah satunya dipengaruhi oleh adanya raport yang baik antara guru bimbingan dan konseling dengan konseli. Selain itu, bullying dapat ditangani melalui pelayanan bimbingan dan konseling yang efektivitasnya salah satunya dipengaruhi oleh empati guru BK seperti halnya yang telah diupayakan oleh guru bimbingan dan konseling di Madrasah Aliyah Negeri Kota Salatiga. Keberhasilan konseling, menurut Kroth (1973: 140-141), Geldard dan Geldard dalam Corey (2010: 99100), serta Semiun (2010: 360, 488-489), hanya tercapai ketika konseli, yaitu korban/pelaku saksi bullying, yang mengalami pemasalahan psikologis bertemu dengan konselor yang adekuat dan kongruen yang berempati kepadanya. Hal ini menimbulkan hubungan dua arah yang selaras dan harmonis. Semakin besar empati, semakin efektif proses konseling. Melalui empati yang baik, konselor mampu memperluas kesadaran korban/pelaku/saksi bullying dari yang semula tidak tahu menjadi menyadari perilakunya. Ketika konselor tidak mengetahui dan memahami posisi dan kondisi korban/pelaku/saksi bullying, kecil kemungkinan untuk menjernihkan pandangan korban/pelaku/saksi bullying. Hal ini penting karena kesadaran diri adalah titik tolak dan bekal korban/pelaku/saksi bullying 
untuk dapat menyelesaikan permasalahannya atau mengubah perilakunya secara mandiri.

Dari segi komponen program bimbingan dan konseling, ranah intervensi kasus bullying pada siswa Madrasah Aliyah Negeri Kota Salatiga idealnya meliputi seluruh komponen dalam program bimbingan dan konseling, yaitu dalam pelayanan dasar, pelayanan responsif, pelayanan perencanaan individual, dan dukungan sistem. Alternatif dalam pelayanan dasar dapat mewujud dalam bentuk identifikasi fenomena bullying di kalangan siswa, kecenderungan siswa terhadap perilaku bullying, dan identifikasi pemahaman siswa tentang konsep bullying. Hal ini bukanlah suatu hal yang mudah, mengingat perilaku ini dalam realitanya sukar dibedakan dengan perilaku "agresif" lain. Dari segi layanan responsif, upaya penangan kasus bullying melalui pelayanan ini telah dikembangkan oleh guru BK MAN Kota Salatiga dalam membantu korban dan pelaku bullying. Dalam hal ini, intervensi yang juga perlu dikembangkan adalah pengoptimalan peran para saksi bullying. Bagaimanapun juga, saksi bullying merupakan potensi yang luar biasa apabila memperoleh intervensi yang tepat. Saksi bullying seyogyanya dikuatkan agar tidak mengikuti atau melakukan perbuatan yang disaksikannya. Malah perbuatan tersebut seyogyanya dijadikan pelajaran untuk bagaimana bersikap secara tepat untuk kedepannya. Keberadaan saksi bullying ini sangat strategis untuk membantu korban dan membatasi gerak pelaku bullying. Tujuan intervensinya difokuskan untuk meningkatkan kemauan dan kemampuan saksi bullying dalam membuat keputusan untuk membela korban. Dengan demikian, saksi bullying dapat mengatasi diskrepansi yang dialaminya sehingga meminimalkan risiko gangguan terhadap kesehatan mental saksi bullying serta berperan aktif dalam mengkounter bullying. Dalam hal ini, keberadan saksi bullying dapat menjadi salah satu jalan memutuskan rantai bullying yang patut diperhitungkan.

Faktor sistem yang melingkupi siswa juga dimungkinkan menjadi faktor munculnya perilaku bullying sehingga dukungan sistem perlu dioptimalkan untuk mencegah dan mengatasi bullying secara sistemik. Hal ini didasari atas urgensi pendekatan/sudut pandang yang mengkaji fenomena tersebut dengan memperhitungkan faktor sistem yang melingkupi siswa di samping pendekatan tradisional yang menempatkan faktor individual untuk mengkaji keterlibatan siswa dalam bullying. Menurut penelitian Nassem yang menyorot bullying dari wawasan tentang pengalaman unik siswa menurut sudut pandang siswa itu sendiri, ketidaksetaraan/kesenjangan di sekolah turut menjadi penyebab 
keterlibatan siswa dalam tindakan bullying karena siswa merasa dipaksa untuk memperkuat kesenjangan sosial tersebut, dimana siswa yang rentan menjadi korban dapat mencapai status yang lebih kuat melalui bullying (Nassem, 2017). Dalam hal ini, sekolah perlu menciptakan sistem yang mendukung upaya meminimalkan bullying di lingkungan sekolah melalui program antibullying/antiperundungan yang jenisnya disesuaikan dengan karakteristik sekolah tersebut. Program anti-bullying di sekolah yang diwujudkan dengan pelatihan orang tua, pengawasan yang lebih baik, metode disipliner, konferensi sekolah, video, informasi untuk orang tua, bekerja dengan teman sebaya, aturan kelas, dan manajemen kelas dapat efektif untuk menurunkan 20-23\% bullying di sekolah (Ttofi \& Farrington, 2009). Yang lebih penting, dukungan sistem juga dapat diwujudkan dalam pendekatan-pendekatan positif melalui program sekolah ramah dan pendidikan kedamaian yang mengedepankan terciptanya budaya damai di sekolah.

\section{Simpulan}

Dari hasil kajian ini dapat ditarik simpulan bahwa dari sekian siswa didapatkan rata-rata pemahaman siswa terhadap konsep bullying adalah sebesar $73,41 \%$, rata-rata keterlibatan siswa sebagai korban dan pelaku bullying adalah $34,13 \%$ dan 34,25\%, sedangkan keterlibatan siswa sebagai saksi bullying adalah $44,76 \%$. Terdapat perbedaan rata-rata pemahaman konsep dan keterlibatan siswa dalam bullying antara laki-laki dan perempuan. Intervensi yang dilakukan oleh guru BK MAN Kota Salatiga lebih terfokus pada peningkatan layanan responsif berupa upaya kuratif terhadap korban dan pelaku bullying, sedangkan terkait bentuk ideal program BK yang spesifik menangani kasus bullying dilakukan secara komperhensif dalam bingkai pelayanan dasar, pelayanan responsif, pelayanan perencanaan individual, dan dukungan sistem terhadap pelaku, korban, maupun saksi bullying.

\section{Daftar Pustaka}

Arseneault, L., Bowes, L., \& Shakoor, S. 2010. Bullying Victimization in Youths and Mental Health Problems: 'Much Ado about Nothing'?. Psychological Medicine, 40 (5), 717-729. doi:10.1017/S0033291709991383

Belman, J. \& Flanagan, M. 2009. Designing Games to Foster Empathy. Cognitive Technology, Vol. 14 (2), 5-15. Retrieved http://www.tiltfactor.org/wp- 
content/uploads2/cog-tech-si-g4g-article-1-belman-and-flanagan-designinggames-to-foster-empathy.pdf

Bond, L., Carlin, J. B., Thomas, L., Rubin, K., \& Patton, G. 2001. Does Bullying Cause Emotional Problems? A Prospective Study of Young Teenagers. BMJ, 323. doi: https://doi.org/10.1136/bmj.323.7311.480

Coloroso, B. 2007. Stop Bullying (Memutus Rantai Kekerasan Anak dari Prasekolah hingga SMU). Jakarta: Serambi.

Corey, G. 2010. Teori dan Praktek Konseling \& Psikoterapi, cet. ke-6. Bandung: PT Refika Aditama.

Departemen Pendidikan Nasional. 2008. Penataan Pendidikan Profesional Konselor dan Layanan Bimbingan dan Konseling dalam Jalur Pendidikan Formal.

Direktorat Jenderal Peningkatan Mutu Pendidik dan Tenaga Kependidikan. 2007. Rambu-Rambu Penyelenggaraan Bimbingan dan Konseling dalam Jalur Pendidikan Formal (ttp.: t.p).

Farida, 2017. Tri Sukses Melalui Bimbingan Dan Konseling Pendidikan Sesuai Faktor Sosial Budaya. Konseling Edukasi: Journal of Guidance and Counseling Vol. 1 No (1).

Farrington, David \& Baldry, Anna. 2010. Individual Risk Factors for School Bullying. Journal of Aggression, Conflict and Peace Research, 2010, Vol. 2 Issue: 1, pp.416, https://doi.org/10.5042/jacpr.2010.0001

Febrini, Deni. 2011. Bimbingan Konseling.Yogyakarta: Teras.

Frey, Karin S. 2005. Gathering and Communicating Information about School Bullying: Overcoming "Secrets and Lies". Health Education, 2005, Vol. 105 Issue: 6, pp.409-413, Https://doi.org/10.1108/09654280510630759

Gibson, Robert L. dan Mitchell, Marianne H. 2011. Bimbingan dan Konseling, terjemahan oleh Yudi Santoso. Yogyakarta: Pustaka Pelajar.

Goleman, D. 1999. Emotional Intelligence. Jakarta: Gramedia Pustaka Utama.

Hawrylak, Alicia Raia \& Donoghue, Christopher. 2016. Assessing the Impact of Emerging Anti-Bullying Legislation on Children and Youth. Education Youth and Today. Published online: 27 Jul 2016; 167-184. https://doi.org/10.1108/S1537-466120160000020007

Jacobsen, K. \& Bauman, S. 2007. Bullying in Schools: School Counselors' Responses to Three Types of Bullying Incidents. Professional School Counseling, 11 (1), 19. https://doi.org/10.5330/PSC.n.2010-11.1

Kartadinata, Sunaryo, dkk., 2008. Penataan Pendidikan Profesional Konselor dan Layanan Bimbingan dan Konseling dalam jalur Pendidikan Formal, Jakarta: Departemen Pendidikan Nasional. 
Kroth, J. A. 1973. Counseling Psychology and Guidance: an Overview in Outline. Illinois: Charles C. Thomas.

Lösel, Friedrich \& Bender, Doris. 2011. Emotional and Antisocial Outcomes of Bullying and Victimization at School: a Follow-up from Childhood to Adolescence. Journal of Aggression, Conflict and Peace Research, 2011, Vol. 3 Issue: 2, pp.89-96, https://doi.org/10.1108/17596591111132909

Mappiare, A.T. 2011. Pengantar Konseling dan Psikoterapi, edisi ke-2, cet. ke-8. Jakarta: PT Rajagrafindo Persada.

Marsudi, Saring. 2010. Layanan Bimbingan Konseling di Sekolah. Surakarta: Muhammadiyah University Press.

McGee, Tara Renae, at al. 2011. Young Adult Problem Behaviour Outcomes of Adolescent Bullying. Journal of Aggression, Conflict and Peace Research, 2011, Vol. 3 Issue: 2, pp.110-114, https://doi.org/10.1108/17596591111132936

McIntyre, T. \& Franks, A. http://www.behavioradvisor.com/Bullying.html

Nassem, Elizabeth Mary. 2017. The Complexity of Children's Involvement in School Bullying. Journal of Children's Services, Vol. 12 Issue: 4, pp.288-301, https://doi.org/10.1108/JCS-03-2017-0009

Nassem, Elizabeth Mary. 2017. The Complexity of Children's Involvement in School Bullying. Journal of Children's Services, Vol. 12 Issue: 4, pp.288-301, https://doi.org/10.1108/JCS-03-2017-0009

Nurihsan, A. J. 2005. Strategi Layanan Bimbingan dan Konseling, cet. ke-1. Bandung: PT Refika Aditama.

Nurihsan, Achmad Juntika. 2011. Bimbingan dan Konseling dalam Berbagai Latar Kehidupan. Bandung: PT Refika Aditama.

Nurlatifah, Andar I. 2017. "Urgensi Empati Konselor/Guru BK dalam Penanganan Bullying di Sekolah". Proceedings International Conference on Indonesian Islam, Education, and Science (ICIIES)2017-Book Two, 422-429.

Olweus, D. 1996, Bullying at School: Knowledge Base and an Effective Intervention Program. Annals of the New York Academy of Sciences, 794:265-276. doi: 10.1111/j.1749-6632.1996.tb32527.x

Rahman, Hibana S. 2003. Bimbingan dan Konseling Pola 17. Yogyakarta: UCY Press.

Regoli, R. M. \& Hewitt, J. D. (2006). Deliquency in Society, Sixth Edition. New York: McGraw Hill.

Rivers, I., Poteat, V. P., Noret, N., \& Ashurst, N. 2009. Observing Bullying at School: The Mental Health Implications of Witness Status. School Psychology Quarterly, Vol. 24, No. 4, 211-223. Retieved http://www.apa.org/ pubs/journals/releases/spq-24-4-211.pdf 
Samnani, Al Karim. 2013. "Is This Bullying?" Understanding Target and Witness Reactions. Journal of Managerial, 2013, Psychology, Vol. 28 Issue: 3, pp.290305, https://doi.org/10.1108/02683941311321196

Sciarra, Daniel T. 2004. School Counseling: Foundation and Contemporary Issues. Belmont: Thomson.

Semiun, Y. 2010. Kesehatan Mental 3, cet. ke-5. Yogyakarta: Penerbit Kanisius.

Suherman, Uman. 2007. Manajemen Bimbingan dan Konseling. Bekasi: Madani Production.

Ttofi, Maria \& Farrington ,David. 2009. What Works in Preventing Bullying: Effective Elements of Anti-Bullying Programmes. Journal of Aggression, Conflict and Peace Research, 2009, Vol. 1 Issue: 1, pp.13-24, https://doi.org/10.1108/17596599200900003

Wolke, D., Copeland, W. E., Angold, A., \& Costello, E. J. 2013. Impact of Bullying in Childhood on Adult Health, Wealth, Crime, and Social Outcomes. Psychological Science. Retrieved http://pss.sagepub.com/content/early/ 2013/08/16/ $\underline{0956797613481608}$

Yen, Cheng-Fang. 2010. School Bullying and Mental Health in Children and Adolescents. Taiwanese Journal of Psychiatry (Taipei), Vol. 24, No. 1. Retrieved www.sop.org.tw/publication/Upload_files/24_1/002.pdf 